https://doi.org/10.52058/2786-5274-2021-2(2)-86-100

Іляшко Олександр Олександрович кандидат юридичних наук, директор Навчально-наукового гуманітарного інституту, Таврійський національний університет імені В.I. Вернадського, вул. Джона Маккейна, 33, м. Київ, 01042, тел.: (067) 910-10-03, e-mail: lex.alex@ukr.net, https://orcid.org/0000-0001-8047-6364

Федоренко Максим Владиславович аспірант Навчально-наукового гуманітарного інституту, Таврійський національний університет імені В.I. Вернадського, вул. Джона Маккейна, 33, м. Київ, 01042, тел.: (044) 529-05-16, e-mail: lermont98@gmail.com, https://orcid.org/0000-0003-4392-7124

\title{
ПРАВОВІ АСПЕКТИ ФОРМУВАННЯ КОЗАЦТВА, КОЗАЦЬКОЇ ДЕРЖАВИ ТА ОСНОВ ПУБЛІЧНОЇ СЛУЖБИ НА УКРАЇНСЬКИХ ЗЕМЛЯХ У КІНЦІ ХV СТ. - XVI СТ.
}

Анотація. Досліджується походження феномену козацтва у кін. XV ст. на теренах Литви, Польщі, Московії та Кримської орди та виокремлення на поч. XVI ст. спільноти українських козаків; аналізуються спроби створення Козацької держави у XVI ст., до підписання Люблінської угоди 1569 року та утворення Речі Посполитої. Узагальнюються та систематизуються погляди українських i зарубіжних (польських, французьких, російських) літописців, істориків та правників на походження слова «козак», а також на сутність, зміст і призначення козацтва у тогочасному суспільстві та в державному житті й самоврядних містах.

Звертається увага на суперечливість описів історії зародження козацтва на Україні та перших керівників козаків. Досліджуються свідчення істориків про вплив чинника П. Лянцкоронського, який першим організував розрізнені загони козаків для оборони окраїн (України) від свавілля та мародерства «степу» (кочівників). Вивчаються взаємовідносини козацьких самоврядних організацій 3 ордами (Кипчакською, Ногайською, Казанською, Астраханською, Поволзькою, Киркильською, Манкопською та Кримською), які утворились після послаблення Золотої орди, а також з Московським князівством, Литвою та Польщею.

Надається оцінка можливостям утворення Козацької держави до укладення Люблінської унії та обгрунтовується висновок про іiі вплив на розвиток українського державотворення в XVI і наступних століттях. Визначаються сутнісні риси козацтва, як прототипу неаристократичної моделі воєнно-цивільної служби, відмінної від зароджуваної в цей же час шляхти. Обгрунтовується висновок про подальший вплив козацтва та ідеології й традицій Козацької держави на становлення то розвиток публічної служби в Україні в бездержавний період. 
Ключові слова: козацтво, козаки, козацька держава, військова служба, цивільна служба, Люблінська унія, шляхта.

Iliashko Oleksandr Oleksandrovych Candidate of Juridical Sciences, Director of the Educational-Scientific Humanitarian Institute, V. I. Vernadsky Taurida National University, John McCain St., 33, Kyiv, 01042, tel.: (067) 910-10-03, e-mail: lex.alex@ukr.net, https://orcid.org/0000-0001-8047-6364

Fedorenko Maksym Vladislavovych Graduate student of the EducationalScientific Humanities Institute , V. I. Vernadsky Taurida National University, Kyiv, 01042, John McCain St., 33, tel.: (044) 5290516, e-mail: lermont98@gmail.com, https://orcid.org/0000-0003-4392-7124

\section{LEGAL ASPECTS OF FORMATION OF THE COSSATIANS, THE COSSACK STATE AND THE FUNDAMENTALS OF PUBLIC SERVICE IN THE UKRAINIAN LAND AT THE END OF THE XV-XVI CENTURY}

Abstract. The origin of the phenomenon of the Cossacks in the end. XV century in Lithuania, Poland, Muscovy and the Crimean Horde and the separation at the beginning XVI century community of Ukrainian Cossacks; attempts to create a Cossack state in the 16th century, before the signing of the Lublin Treaty of 1569 and the formation of the Commonwealth are analyzed. The views of Ukrainian and foreign (Polish, French, Russian) chroniclers, historians and lawyers on the origin of the word "Cossack", as well as on the essence, meaning and purpose of the Cossacks in the society of that time and in state life and self-governing cities are generalized and systematized.

Attention is drawn to the contradictory descriptions of the history of the origin of the Cossacks in Ukraine and the first leaders of the Cossacks. The testimonies of historians about the influence of the factor P. Lyantskoronsky, who was the first to organize separate detachments of Cossacks to defend the outskirts (Ukraine) from arbitrariness and looting of the "steppe" (nomads), are studied. The relations of Cossack self-governing organizations with hordes (Kipchak, Nogai, Kazan, Astrakhan, Volga, Kirkil, Mankop and Crimean), which were formed after the weakening of the Golden Horde, as well as with the Moscow principality, Lithuania and Poland are studied.

The possibilities of formation of the Cossack state before the conclusion of the Lublin union is estimated and the conclusion about its influence on development of the Ukrainian state formation in XVI and subsequent centuries is substantiated. The essential features of the Cossacks as a prototype of a non-aristocratic model of militarycivil service, different from the nobility born at the same time, are determined. The conclusion about the further influence of the Cossacks and the ideology and traditions of the Cossack state on the formation and development of public service in Ukraine in 
the stateless period is substantiated.

Keywords: Cossacks, Cossacks, Cossack state, military service, civil service, Lublin Union, gentry.

Постановка проблеми. Загальновідомо, що становлення державної (цивільної, публічної) служби виникає з утворенням самих держав, у яких уже сформовано публічно-світський компонент забезпечення влади монарха. Як правило, цей компонент, подібно самому монарху, має аристократичне походження та привілеї щодо воєнної та цивільної служби. Прикладом цього може бути становлення в кін. XV ст. - XVI ст. шляхти у Польщі.

Сучасні автори «Нарисів з історії Польщі» пишуть про те, що з другої пол. XIV ст. польське суспільство ділилося на стани 3 різноманітними політичними повноваженнями. Такими станами у Польщі були духовенство, шляхта, міщани i селяни. При цьому, виключно важливу роль у державно-політичних справах належала иляхті, яка виникає 3 cеp. XIV ст. «з середньовічного лицарства, досить розрізненого у свої масі, завдяки здобуттю від монарха привілеїв, щзо надавались вже не для певної групи, а для загалу лиизарства» [1, с. 52].

Утім, генезис шляхти мав у Польщі цілком конкретне походження, описане в значній кількості наукових розвідок як польських, так і інших істориків. Так, на думку російського дослідника історії дворянства М. Яблочкова, з сер. XIV ст. у Південно-Західних областях, поряд з попередніми боярами, з'явились Польські пани i Литовські бояри. «Ці три елементи (туземний, польський і литовський) змішалися та утворили один вищий стан, який раніше навіть ніж у північній Росії отримав назву дворянства (1492 р.), потім шляхти» [2, с. 101], писав М. Яблочков.

Відзначимо, що Польща не знала формального поділу на низову, середню та горішню (аристократичну) шляхту, властиву феодально-аристократичному устрою держав Західної Свропи. Але, такий поділ в середовищі шляхти існував фактично. Горішню верству шляхти становили магнати, які володіли великими палацами i маєтками i, по-суті, визначали політику держави через своїх представників (послів) у королівській раді. Найбільш численним був прошарок середньої шляхти, представники якої володіли декількома селами. Натомість низова шляхта за своїм економічним статусом мало чим відрізнялась від заможних селян. 3 часом з низової шляхти виділяється дрібна збідніла шляхта або ж т.3. «голота».

Шляхта була доволі замкнутою соціальною верствою, а шляхетство набувалась за народженням чи надавалось за заслуги перед державою (нобілітація). Останній спосіб входження до стану шляхти, на наш погляд, був прологом до утвердження в Польщі адміністративного режиму державної служби.

Починаючи із сер. XV ст. панівний стан і привілеї шляхти у Польщі постійно зростали і зміцнювались. Як писав М. Устрялов, «звання шляхетське було спадковим, переходило від батька до дітей $i$ поєднувалося зі значними перевагами: иляхтич не платив жодних податків, володів своєю землею та 
селянами непідзвітно, брав участь у повітових Сеймиках $і$ генеральних Сеймах, якщо був обраний у Нуниї, вступав у всі почесні земські посади, також в інші гарні звання. Благородне походження, засвідчене законним чином, герб, затверджений Сеймом, виключне заняття військовою чи циивільною службою, ось головні умови, які в сукупності давали право на звання Шляхтича» [3, с. 543].

У цей час на Українських землях дозрівало козацтво, яке 3 часом стало політичною, воєнною та публічно-управлінською елітою України і серйозним суперником шляхти. Так, П. Куліш у своїй роботі «Історія воз’єднання Русі» писав про сутність і походження козацької верстви наступне: «Ратоборцями невизнаного панами права народної маси були люди, які на початку стали необхідним знаряддям для успіху колонізації українських пустель, а потім опинилися поза законом і постали супроти всіх прагнень шляхти, - саме українські козаки» [4, с. 31].

Щодо передумов і причин зародження козацтва О. Єфіменко писала, що Південна Русь постійно перебувала під загрозою через абсолютно відкритий кордон зі степом. Очевидно, що «... ні Литовсько-Руська держава, до Люблінської унії, ні Польсько-Литовська після неї, не мали достатньо сил, щуоб належно організувати захист такої віддаленої окраїни, як Південна Русь ... Українське козацтво з'явилося на світ лише тому, щзо під боком існувало розбійниче Кримське ханство» [5, 105].

Разом із тим, наукові розвідки про феномен козацтва в цілому та утвердження українського козацтва, зокрема $\epsilon, 3$ одного боку, досить численними, починаючи 3 історичних хронік XVI ст., а 3 іншого суперечливими. Одні й ті ж історичні умови і події, в яких відбувався генезис козацтва, подаються українськими, польськими, російськими, білоруськими, литовськими, французькими i іншими істориками давнини i сучасності по різному. Врешті, учені так і не дійшли єдності щодо етимології слова «козак» та щодо належності козаків до конкретного тогочасного державного утворення, культури, етносу тощо.

Так українські дослідники писали про інтерпретації слова «козак» наступне. М. Василенко вбачав, шо: «Козак - людина вільна, бездомна, нікому не підлегла, та, шзо служить за гроші, кому захоче. ... незалежний, шукач військових пригод ...» [6, с. 117]. Натомість, А. Копистянський стверджував, що слово «козак», 3 татарського «кайзак» буквально означало «розбійник» чи «волоцюга». «Так називали татари своїх воїнів, які свобідно жили на пограничу Криму $і$ на власну руку запускалися в степ, де промишляли ловецтввом і розбишацтвом» [7, с. 246].

Достовірним фактом є лише поява на поч. XVI ст. зорганізованих козацьких загонів П. Лянцкоронського на теренах сучасної України, які боронили населені пункти від т.з. «Стпепу», численних орд, які виокремилися з занепадом Золотої орди.

Аналіз останніх досліджень і публікацій. Проблематика щодо походження козаків в Україні є традиційною для українських, польських, французьких, 
російських і інших істориків, філософів і правників. Її дослідження стало предметом ретельних, хоча нерідко й еклектичних наукових розвідок таких українських учених, як В. Антонович і В. Бец [8], І. Бєляєв [9], Д. БантишКаменський [10], М. Василенко [6], М. Грушевський [11], О. Єфіменко [5], Г. Кониський [13], А. Копистянський [7], П. Куліш [14], М. Маркевич [15], Н. Полонської-Василенко [16], Д. Яворницький [17] і ін. [18, 19]; російських науковців - М. Устрялова [3], М. Яблочкова [2] і ін.; французьких дослідників Г. де Боплана [19], П. Шевальє [20], австрійського історика Й.-Х. Енгеля [21], а також польських дослідників - А. Яблонського та ін. [1].

Важливими для підготовки цієї статті стали і грунтовні дослідження історії козацтва та Козацької держави, проведені сучасними українськими дослідниками. Це, зокрема, монографії Н. Яковенко «Українська шляхта 3 кінця XIV - до середини XVII століття. Волинь і Центральна Україна» (2008р.) [22], В. Смолія та В. Степанкова «Українська національна революція XVII ст. (1648-1676 рр.)» (2009 р.) [23], грунтовна 2-х томна наукова робота В. Шевчука «Козацька держава як ідея в системі суспільно-політичного мислення XVI-XVIII століть» у двох книгах (2019р.) [24] і ін. Зокрема, й відповідна наукова публікація співавтора цієї статті М. Федоренка [25].

Разом із тим, проблематика зародження козацтва та розвиток шляхти у кін. XV ст. - до Люблінської унії 1569 р., як певного прологу формування інституту державної (цивільної) служби в Україні та Польщі, зберігає свою актуальність для правничої науки і публічного управління.

Мета дослідження полягає в аналізі генезису козацтва у кін. XV ст. - до Люблінської унії 1569 р., як предтечі української державності та зародження основ воєнно-цивільної служби, а також виявленні сутнісних ознак козацької служби і їі відмінності від служби шляхти і бояр.

Виклад основного матеріалу. Щодо часу та причин появи козаків, погляди дослідників із цього питання фактично співпадають. Хоча, нерідко зустрічаються й екскурси істориків у «сиву прадавнину» козацтва. Так, За М. Карамзіним, козаки були відомі на «окраїні теперішньої Росії» раніше Батиєвої навали, і виступили на історичну сцену іще в Х ст. «то під ім'ям торков і берендєєв, то черкасов і просто казахів чи козаків» [26, с. 11].

Автор легендарної для України 3-томної наукової розвідки «Історії Запорозьких козаків» Д. Яворницький також висловлював думку, що слово «козак» стає відомим із XI ст. і означає на мові половців «сторожа, передова, нічна та денна» $[17$,$] . Але, у XII ст. - cep. XV ст. згадок про козаків не$ зустрічаємо в жодному відомому джерелі. Натомість, перші згадки про козаків у їх звичному для сучасників значенні Д. Яворницький відносив до 1469 року, коли «багаточисленне татарське військо, сформоване за Волгою із втікачів, розбійників і вигнанців, за словами польського історика Длугоша, пройшло від Волги за Дніпр і спустошило Поділля». [17, с. 7]. 
Д. Бантиш-Каменський вбачав, що козаки переселилися за Дніпро із Кавказу. Утім, козаки не складали ніколи єдиного народу; «подібно римлянам зобов 'язані існуванням свойм війнами. Неможна достовірно встановити час їх появи у циих місиях, але він настав не раніше XV cm.», писав Д. Бантиш-Каменський, спираючись на покази Бєльського про те, що козаки стали відомими в Польщі лише на поч. XVI ст. [10, с. 64].

Слід звернути увагу й на твердження М. Маркевича, який апелює до мізерної численності козаків на поч. XVI ст. (не більше 2 тис. козаків станом на 1535 p.), i писав, що вони «... не могли бути засновниками родоводу усіх Малоросів, не могли також бути залишками Торків, ні вихідиями із гір Кавказу; але були блукачами із тих же Малоросіян, посиленими приданими до них від Короля та Гетьмана городовими і земськими козаками» [15, с. 31]. Тобто, М. Маркевич, грунтуючись на незначній чисельності козаків, спростовує їх етнічне походження, як «окремого народу».

У свою чергу, І. Бєляєв писав про городових козаків, які були «особливим класом служилих воїнських людей» в «украӥнських або прикордонних містах», перебували на постійній службі та доповідали про рух татар у степу, перехоплювали татарських «язиків», доставляли вісті воєводам. До складу городових козаків набиралися вільні люди, які отримували наділи землі та вивільнялись разом із своїми сім'ями від оподаткування. Уперше в літописах городові козаки зустрічаються в 1444 році при описі битви із царевичем Мустафою [9, с. 2-3].

Дослідник історії дворянства М. Яблочков також писав, що перші згадки про козаків відносяться до 1444 року. За його свідченням, козаки, що постали на противагу Південно-Руській шляхті, - це був «збрід прийдешніх $i$ біглих зі всіх кінців. Вони складали найнижчий прошарок населення; але із поміж них виділялися Запорожиі, козаки, що жили у Придніпров'ї й не підпорядковувалися нікому. Козаки зберігали і міџно стояли за православну віру, не тягнули ні до Росії, ні до Польщі, ні до Криму, але за нагоди грабували $і$ одних, і інших та завжди відчували неприязнь до своїх ополячених панів - католиків» [2, с. 102]. Також М. Яблочков писав про утвердження в Московському князівстві в сер. XV ст. служби придворної, військової та цивільної, які іще не поділялися між собою та характеризує основний елемент цієї служби - татарський, литовський, грецький і різних удільних князів. При цьому, козаків він не згадує в жодній із категорій служивого стану Московського князівства.

Схожі погляди на час і умови виникнення козацтва висловлював у першій пол. XIX ст. і російський історик М. Устрялов. Зокрема, він стверджував, що «ім'я Козаків зустрічається в наших літописах іще в половині XV століття; так на той час звалися бездомні молодці, безсімейні, самостійно рекрутовані на подвиги ратні, в особливості на війну з бусурманами. Відчужуючи всілякі суспільні зв'язки, вони не терпіли ні сіл, ні міст, жили на украӥнах чи у степах, що 
прилягали до прикордонних міст, стерегли їх від раптового нападу, даючи знати про появу ворогів, нерідко й самі грабували міста, які бралися захищати, частково від молодецтва, частко від незадоволення. ... Козацтво ... було воєнним братством, що мало свої статути: його стихією була війна; головним правилом споконвічна ненависть до бусурманів і безгранична воля. Отаман водив Козаків у битви, ділив здобич, але мав доволі обмежену владу: всі справи вирішувались спільним рішенням у Козацьких кругах. Подібне братство з'явилося в той же час на Дніпрі, за порогами» [3, с. 64-66].

М. Грушевський, на основі аналізу польських архівних джерел, засвідчує достовірні згадки про козаків Київщини в 1492, 1493 і 1499 роках. Але козацтво, тоді було способом життя й родом занять для багатьох молодих людей, які ходили «в козаки» для походів на татар чи для «луплення татарських чабанів», а не козацькою верствою [11, с. 204]. П. Шевальє також писав, що коли надходила осінь, «кожен з ичих сміливців вертався додому, умовивиись зустрітися весною на островах $i$ порогах Борисфену, щзоб звідти знову робити свої nоходи» [20, с. 34]. Тобто, «козакування» на ранніх етапах було певною формою соціалізації молодих неодружених чоловіків, які прагнули до звитяги і заробітків.

Козацтво, як відома верства українського населення, утверджується в традиційному для сучасників значенні упродовж всього XVI ст. Як писав М. Василенко, «Козацтво зародилося $i$ росло непомітно в умовах життя польської держави. У Польщі козацтво почали помічати тільки тоді, коли воно виросло в вагому суспільну силу» [6, с. 116].

Але, козаки у позначений період були і в воєнних загонах інших держав, що межували, часто без чіткого кордону, з тогочасною Україною. Зокрема, до кінця існування Кримського Ханства, козаками у татар називався особливий кінний загін війська, сформований із уланів і, власне, козаків. Загони козаків також діяли у Московських великих і удільних князів після перемоги Москви у Лівонській війні та із започаткуванням «збирання земель» Іваном III у кін. XV ст. Д. Яворницький також писав про наявність у польських хроніках Пясецького про Щурову козачу роту в м. Черкасах [17, с. 9].

У кін. XV ст. - на поч. XVI ст. потужні козацькі загони діяли і в Українських землях. Так в 1492 р. хан Менглі-Гірей скаржився, за П. Кулішем, - Великому Князю Московському Йоану III, а за М. Василенком - Великому Князеві Литовському Олександрові (1461-1506 рр.), що його військо, повертаючись 3 набігу на Київ із награбованим, зустрілось 3 «ординськими козаками» (за М. Василенко - «із канівськими і черкаськими козаками»), та було ними пограбоване [6, с. 33-34].

У літописах цього періоду також згадуються дніпровські, рязанські, смоленські, путивльські, донецькі та інші козаки. У відповідних виокремлюються воїни різних етносів, навіть у межах одного війська. Так, за свідченням В. Шевчука, у пам’ятці «Битва під Оршею» 1515 р. «... розрізняються воӥни 
литовські, руські та польські, тобто вони перебували в окремих підрозділах одного війська» [24].

Отже, українські козаки-воїни починають зустрічатися в літописах лише на поч. XVI ст. Вони охороняли поселення від набігів татар і турків, охороняли кордони тогочасних громад i палаци князів і магнатів. Зокрема, П. Шевальє писав, що іще С. Баторій оцінив, як козаки можуть бути йому корисними для захисту кордонів від набігів татар та створив із козаків військо, призначив їм гетьмана й уповноважив його дбати про підлеглих офіцерів, потрібних для командування козаками, надавши першим, крім плати, привілеї та вольності [20, с. 34].

Першим достовірно відомим лідером цих козаків був Каменецький староста Предслав Лянцкоронський, який походив із давнього литовського роду Збигнівів [14, 43-44]. Хоча, Г. Кониський у «Історії Русів», вслід за М. Маркевичем, називає його Пренцлавом Лянцкоронським і вказує, що він був зятем князя Острозького та походив із знатної сенаторської родини. У свою чергу, Й.-Х. Енгель вказує, що П. Лянцкоронський, по закінченню своїх студій, подорожував по країнам Європи, їздив до Єрусалиму та Азії, та здобув перші перемоги в боях під проводом К. Ольшанського [21, с. 88].

Подібні погляди на походження та особисті якості та вплив на формування українського козацтва обгрунтовував і Д. Яворницький. «У 1512 рочі козаки, разом із поляками і українськими жителями, брали участь у переслідуванні татарської орди, яка ввірвалася в південні кордони Литовського великого князівства. Начальниками над козаками і поляками були князь Костянтин Іванович Острозький і каменецький староста Предслав Ляндскоронський» [17, с. 9], писав дослідник.

Наслідками воєнної звитяги П. Лянцкоронського були три виграні битви із турками і татарами, які припинили спроби походів останніх на Краків, а також утворення прикордонних воєнних загонів понад Дністром і в гирлі Дніпра. Утвердженню воєнного авторитету П. Лянцкоронського відбулося й завдяки його співпраці зі старостою Чернігівським і Канівським Остафієм Дашкевичем у протистоянні сваволі татар [21, с. 89]. Д. Яворівський писав, що «Євстафій або Остап Дашкевич, спершу литовський воєвода, потім черкасько-канівський староста, уродженець міста Овруча, людина православної віри ... воював спочатку проти татарами (у 1523 році), служив декілька років великим руським князям Івану та Василію, допомагав їм у війні проти поляків, потім знову повернувся в Литву до Сигізмунда, і отримав в управління міста Черкаси і Київ на правому березі Дніпра нижче Києва. Управляючи цими містами, він залучив до себе таку масу козаків, що зробив обидва міста надовго ядром усього південноруського козацтва» [17, с. 10]. І лише із захопленням Стародуба в 1535 році, як писав М. Маркевич, «ім'я Дашковича замовкло» [15, с. 44].

Врешті, як писав Г. Кониський, «приймаючи прихожих охотників (M.Ф. - в nер. $з$ польської «добровольц̧ів») з нежонатих козаків, ловлею звірів та риби, а не 
менше здобиччю заграничною спроваджених, створили велелюдне товариство козацьке» [13, с. 23-24]. 3 часом остаточними пунктами збору козацьких загонів стали Київ і Черкаси.

Слід також прийняти до уваги думку А. Копистянського про те, що значні простори між Києвом і Брацлавом спустошились і замінилися в т.з. «дикі поля», що становили нейтральну полосу між Литовською, а після Люблінською унії 1569 р. - Польською державою і Кримським ханством. «Киїщиина, котра колись була головним осередком і ядром Руси, в XVI cm. найшлася «у краю» ПольськоЛитовськоӥ держави, тобто там, де закінчувався «святоруський берег» $i$ зачиналось изарство Кримської Орди. По тій причині Київщина в XVI ст. почала називатися Україною», - писав А. Копистянський [7, с. 245]. Ї̈̈ ж охорона почала у цей час здійснюватися організованими козацькими загонами.

При цьому, загроза Українським землям 3 боку Кримської орди з часу утвердження козацтва лише наростала. Так, за свідченням С. Плохія, «кількість українців і росіян, які потрапили на невільницькі ринки Криму в XVI та XVII століттях, коливається від 1,5 до 3 млн. осіб» [19, с. 113]. Водночас, як писав I. Бєляєв, уже із 1556 року й козаки, що охороняли українські міста, почали проникати у степ для нападу на Кримців [9, с. 6]. Натомість, М. Маркевич зазначає про іще більш ранні походи П. Лянцкоронського на Кримців іще в 1512 р. [15, с. 36].

Як писав М. Грушевський, «упродовж XVI ст. дуже повільно формується 3 цих «козакуючих» козацький стан. У половині XVI ст. бачимо тільки початки цього процесу; у головному гнізді козацтва - Черкасах ревізія 1552 р. записує прихожих козаків «опівтритьяста» (біля 250), - тільки всього. ... але, майже i зовсім не було козацького стану. Останній формується тільки в кін. XVI і на поч. XVII ст., завдяки надзвичайно швидкому зростанню козацтва і під впливом, 3 одного боку, колонізаційного зростання українського передстепу, а з іншого, ідеї козацького імунітету» [11, с. 205]. Такий імунітет, за аналогією з імунітетом польської шляхти, мав захистити козаків від місцевих влад і захистити від спроб, спочатку Литовської держави, а після Люблінської унії 1569 р. і Речі Посполитої, організувати козацький стан у державні воєнні організації.

Як відомо, Люблінська унія, укладена спільним Польсько-литовським сеймом у м. Любліні з 10 січня по 12 серпня 1569 р., поклала початок Речі Посполитої Обох Народів, яка проіснувала до 1795 року. Цей державотворчий поступ сприяв розквіту Польського Відродження та шляхетській демократії, яка зосередилась у місцевих сеймиках [25, с. 128].

Вершиною шляхетської держави стали практики «Золотої вольності» обрання короля Польщі шляхтою на основі Генриківських статей 1573 p. iз складенням особистих зобов'язань (pacta conventa) кандидатів на трон перед шляхетською спільнотою. Перша вільна елекція (вибори) короля відбулася в 1872 р. після смерті бездітного Зигмунта II Августа. Хоча цей принцип престолоспадкування утвердився раніше, на межі XV i XVI ст. Ця практика виявилась прийнятною для Польщі й у подальшому застосовувалась до самої 
загибелі Речі Посполитої в 1795 році. До того ж, у кінці XVI ст. владу короля в Польщі почав урівноважувати Сейм [1, с. 67].

Наслідки утвердження Речі Посполитої мали для України і козацтва мали драматичний характер. Як писала Н. Василенко-Полонська, «Україна була розірвана: більша іiі частина перейшла до Польщі - Галичина, Холмщина, Волинь, Поділля, Брацлавщина, Київщина, Підляшшя. ... Польська шляхта гордливо ставилася до всього чужого, і перед українцями постала дилема: або зректися політичного життя, або полонізуватся [16, с. 343-344]. Інші Українські землі також були розтягнуті Московією, Литвою, Молдовою, Туреччиною та Угорщиною.

Феноменом тогочасного розвитку України стало прагнення заможного населення окремих регіонів України полонізуватися та нобілітуватися до стану шляхти, що відкривало перспективи для кар'єри на військовій і цивільній службі, надавало певний імунітет, а також дозволяло захистити свою власність. Цьому значною мірою сприяло й надання кролем 3. Августом у 1563 р. привілеї, яка урівнювала православних русинів з польськими католиками у їх правах. Таким чином, Польща по-суті переманила русинську еліту від короля Литви до себе. Полонізації України сприяло і зміцнення Московського царства та початку «собіранія зємєль» після вигнання ним у 1480 році ординців.

Разом із тим, не всі $з$ цих сподіванок українців Волині та Поділля були здійсненними. Так Г. де Боплан писав про руську шляхту наступне: «Шляхта поміж ними небагаточисленна, наслідує польській i, схоже, соромиться того, що належить до іншої, аніж римська, віри, щодня переходячи до неї, хоча вся знать, i всі ті, що титулуються князями, вийшли з грецької віри» [19, с. 32]. Сподівання ж українців Волині та Підляшшя, які плекали надії, що Люблінська унія покладе край безкарним «гвалтам, наєздам, забойствам $і$ забиранню земель, $і$ грабєжам ... панів поляків» [18, с. 198], виявилися марними.

Але, чи не найбільше після утворення Речі Посполитої Обох Народів, як офіційно називалась Унія, погіршився стан українських козаків. Українські дослідники В. Антонович і В. Бець давали наступну оцінку розвиткові козацтва після Люблінської унії: «Тяжкі часи пережсвало Дніпровське козачтво в кін. XVI ст.: внаслідок приєднання Південно-Руських земель до Польщі актом Люблінської уніі 1569 року, польське державне право введене було в изі землі, а по усталеним положенням изього права, козацький стан був аномалією, не міг укластися в станові категорії, напрацуьовані польським історичним життям, мало перейти до складу станів, визнаних законом: дворянського чи селянського» [8, с. 2].

Іще одним визначальним питанням для розвитку козацтва стало запровадження в тогочасну державотворчу практику Речі Посполитої реєстрового козацтва. Так С. Плохій пише, що «Лівонська війна збільиила попит на воїнів на кордоні з Московією, тож у 1570-ті роки було сформовано ряд козацьких підрозділів, один із яких налічував 500 вояків» [19, с. 117]. Реорганізація 
стихійного козацького руху на службі в прикордонних урядовців у військові організації відкрила перед козаками нові перспективи. До вжитку був запроваджений термін «реєстрові козаки». Їх вносили до реєстру як професійних (оплатних) військових і вони не сплачували податків і не підпадали під місцеві юрисдикції.

Так, у 1590 році польсько-литовський сейм затвердив військо в 1000 реєстрових козаків для охорони прикордонних областей України від татар i нереєстрових козаків [19, с. 117]. Але, як підкреслює С. Плохій, всі виплати i пільги козакам діяли лише на період активних військових кампаній. Таким чином, створення реєстрового козацтва не вирішило всі проблеми корпусу козаків в Україні. «Нереєстрове» козацтво, 3 одного боку, продовжувало боротьбу за Козацьку державу, а 3 іншого - боролося за привілеї, які гарантувались включенням до складу реєстрового козацтва.

Ця проблематика отримала своє продовження впродовж усієї історії Речі Посполитої. Так, для прикладу, в першій пол. XVIII ст. зустрічаємо документ 3 промовистою назвою: «Меморандум гетьмана великого коронного Станіслава Конецпольського на сейм 1638 р. із пропозиціями щодо тримання козаків у «послуху» укріплення і утримання гарнізону фортеці Кодак; щодо норм платні старшині реєстрового козацтва, а також щодо необхідності призначення королем або сеймом комісара замість гетьмана, якого козаки вільно обирають; вимоги до кандидатів на посади комісара, осавулів, полковників, сотників, отаманів» [27, с. 322-324]. Таким чином, реєстрове козацтво, по-суті, отримало статус воєнних, які служили короні та підпорядковувались спочатку виборному гетьману, а надалі й призначуваному комісарові.

Така служба мала, по-перше, мілітарний характер, тобто була за своєю сутністю та змістом воєнною службою мобілізаційного (ополченського) типу; nодруге, по друге вона іще не могла бути державною в інтересах України за відсутності на той час національної державності. Козаки і інший т.з. «служивий люд» на поч. XV ст. у Литовсько-Руській державі служили «кінно, збройно, часу потреби війни». При цьому, воєнний обов'язок у цей час не пов'язували з походженням людини - служили всі, хто міг тримати зброю в руках [22, с. 322-28]; по-третє, ядро професійної державної служби в Україні в XVI ст. почало формуватися в різних регіонів 3 декількох станів: а) 3 козаків, зокрема з реєстрових козаків (Черкащина, Канів, Дніпровщина); б) зі шляхти, зокрема, 3 нобілітованої шляхти (Волинь, Брацлавщина, Підляшшя, Холмщина, Київщина); в) з козаків на Півночі України, які служили Московській державі під час «збирання» земель спочатку великим князем Іваном III, Василем III і врешті Іваном IV Грозним (Лютим) (Чернігів, Путивль, Новгород-Сіверський). Кожне із зазначених джерел формування державної служби справило вплив на їі становлення, розвиток, характер і систему управління нею [25, с. 130-131].

Висновки. Підводячи підсумки цього дослідження, відзначимо, що походження феномену козацтва зберігає свою дискусійність в українській, 
польській, російській, литовський, білоруській, французькій і іншій історіографії, присвяченій як вивченню етимології слова «козак», так i дослідженню походження, етнічної приналежності, культури і відношення до держав, державних союзів і державних утворень сер. XV - XVI ст. у регіоні т.з. «Південної Русі», до якої відносилися насамперед Українські землі.

Очевидним вбачається й прагнення окремих зарубіжних літописців i істориків закріпити у своїх роботах певну «монополію» на феномен козацтва за тогочасного Польщею, Литвою чи Московією, або ж апелювати до міфічних козаків, які ніби то існували за пів тисячоліття до українських козаків. Це пояснюється тим, що після розквіту Галицько-Волинської держави на чолі 3 коронованим Папою Римським у 1253 році «Королем Русів» Данилом Галицьким, українці вже в XIV ст. втратили належним чином легітимізовану державність, а їх землі розтягувались сусідніми державами і залишались границею на межі 3 т.з. ординським «Степом».

По-суті, козаки стали відповіддю й на тогочасну бездержавність українців, i на виникнення шляхти у Польщі та бояр у Литві й Московії, а також на загрозу Кримської та інших орд, загроза від яких для українських міст і сіл лише зростала. Творячи Козацьку державу, козаки одночасно формували основи тогочасної воєнно-цивільної служби на Українських землях.

Разом із тим, козаки, на відміну від польської шляхти і литовських та московських бояр, не мали: а) аристократичного походження та не спадкували свій статус (отамани і інші посади у козаків були виборними, а не спадковими), а також були відлучені, принаймні в XVI ст., від можливості отримати дворянські титули; б) в силу несення воєнної повинності, у винагороду земельних латифундій; в) постійної оплати і податкових привілеїв за свою воєнну службу, подібно польській шляхті; в) юрисдикційних імунітетів, подібно тогочасній польській, литовській i московській аристократії; г) були обмеженні щодо отримання посад цивільної служби.

Водночас, українські козаки, як і польська шляхта, у XVI і наступних століттях були прихильниками демократичних традицій. Прагнули до несення воєнної служби на професійній основі та до державотворення й творення публічної служби.

\section{Лimepamypa:}

1. Польща - нариси історії. За ред. В. Менджецького та Є. Брацисевича. Пер. 3 пол. I. Сваренка / Інститут національної пам'яті Республіки Польща. Варшава: Інститут національної пам'яті, 2015. 367 с., іл.

2. Яблочков М. История дворянского сословия в России. С.-Петербург: Типогр. А.М. Котомина, 1876. XVI, XL, 679 с.

3. Устрялов Н.Г. Русская история. Часть вторая (1462-1689). Санктпетербург: В Тип. Императорской Российской академии, 1837. [2], 378 с., 1 л. табл.

4. Кулиш П.А. История воссоеденения Руси. Том первый. От начала колонизации опустошенной татарским погромом Киево-Галицкой Руси до начала столетеней козацко- 
щляхетской войны. С.-Петербург: Изд-е Товар-а «Общественная польза», 1874. IV c., III с., 363 с., прилож. С. 320-363.

5. Ефименко А.Я. История украинского народа. Выпуск первый. Выпуск второй. 9 рисунков в тексте и 12 на отдельных таблицах. С.-Петербург: Типогр. Акц. Общ. БрокгаузЕфрон, 1906. 391 с., ил.

6. Василенко Н.П. Очерки по истории Западной Руси и Украины. Киев: Изд-е книжного магаз. Н.Я. Оглоблина, 1916. 589 с.

7. Копистянський А. Історія Руси. Часть друга: Московска і Литовско-Польска доба (Велика і Мала Русь до часів Б. Хмельницького). Львів: Изданіе Общества ім. М. Качковского, 1932. 343 c., 3 c., 6 c.

8. Антонович В.Б., Бец В.А. Исторические деятели Юго-западной России в биографиях и портретах по коллекции Тарновского В.В. Выпуск первый. Киев: Типограф. Императорского Ун-та Св. Владимира, 1885. VI с., 110 с.; ил.

9. Беляев И. О сторожевой, станичной и полевой службе на Польской Украине Московского государства до царя Алексея Михайловича. Москва: В Университ. типограф., 1840. 86 с.; карт.

10. Бантыш-Каменский Д.Н. История Малой России от водворения словян в сей стране до уничтожения гетьманства. Київ: Час, 1993. 656 с., іл.

11. Грушевский М. Очерки истории Украинского народа. Изд-е третье, дополн. Киев: Типограф. 1-ой Киевской Артели Печати, 1911. 408 с.

13. Кониський Г. История Русов или Малой России. Редакц. і вступ. стат. О. Оглоблина. Нью-Йорк: Вид-во «Вісник» - ООЧСУ, 1956. 346 с.

14. Кулиш П.А. История воссоеденения Руси. Том первый. От начала колонизации опустошенной татарским погромом Киево-Галицкой Руси до начала столетеней козацко-щляхетской войны. С.-Петербург: Изд-е Товар-а «Общественная польза», 1874. IV с., III с., 363 с., прилож. С. 320363.; Кулиш П.А. История воссоеденения Руси. Том второй. От начала козацко-щляхетской войны до восстановления в Киеве Православной Церкви в 1820 году. С.-Петербург: Изд-е Товар-а «Общественная польза», 1874. VIII с., III с., 456 с., прилож. С. 425-456.

15. Маркевич Н. Истрия Малороссии. Изд-е книготорг. О.И. Хрусталева. Том первый. Москва: В Типограф. А. Семена при Императ. Медико-Хирург. Академ., 1842. 387 с., X.

16. Полонська-Василенко Н. Історія України. В двох томах. I том (до пол. XVII сторіччя). Мюнхен: Українське вид-во, 1972. 591 с.

17. Яворницький Д.І. Історія запорозьких козаків. У трьох томах. Редкол.: П.С. Сохань (відп. ред.) і ін. Передм. В.А. Смолія. Том 1. Київ: Наук. думка, 1990. 592 с.; Яворницький Д.І. Історія запорозьких козаків. У трьох томах. Редкол.: П.С. Сохань (відп. ред.) і ін. Том 2. Київ: Наук. думка, 1990. 560 с.; Яворницький Д.І. Історія запорозьких козаків. У трьох томах. Редкол.: П.С. Сохань (відп. ред.) і ін. Том 3. Київ: Наук. думка, 1990. 560 с.

18. Русина О.В. Україна під татарами і Литвою. Київ: Вид. дім «Альтернатива», 1998. 320 с..

19. Плохій С. Брама Європи. Історія України від скіфських воєн до незалежності. Харків: Клуб сімейного дозвілля, 2016. 495 с.

19. Боплан Г. Л. де. Опис України, кількох провінцій Королівства Польского, що тягнуться від кордонів Молдовії до границь Трансильванії, разом з їніми звичаями, способом життя і ведення воєн. Київ: Наукова думка; Кембрідж (Мас.): Укр. наук. ін-т, 1990. 256 с.: іл.

20. Шевальє П. Історія війни козаків проти Польщі, з розвідкою про їхнє походження, країну, звичаї, спосіб правління та релігію і другою розвідкою про перекопських татар. пер. $з$ франц. вид. 1663 року. Київ: Вид-во Акад. наук УРСР, 1960. 199 с.

21. Енгель Й.Х. Історія України та українських козаків. Заг. ред., вступ. стат. В.В. Кравченка; упоряд. Т.О. Чугуя. Харків: Факт, 2014. 640 с. 
22. Яковенко H.M. Українська шляхта з кінця XIV - до середини XVII століття. Волинь і Центральна Україна: монограф. / Укр. наук. ін-т Гарвард. Ун-ту, Ін-т Критики. Вид. 2-ге, перегл. і випр. Київ: Критика, 2008. 469 с.: іл.

23. Смолій В., Степанков В. Українська національна революція XVII ст. (1648-1676 pp.). Київ: Вид. дім «Києво-Могил. акад.», 2009. 447 с.

24. Шевчук В. Козацька держава як ідея в системі суспільно-політичного мислення XVIXVIII століть / У двох книгах. Книга 1. Київ: ТОВ «Вид-во «Кліо», 2019. 792 с., іл.; Шевчук В. Козацька держава як ідея в системі суспільно-політичного мислення XVI-XVIII століть / У двох книгах. Книга 2. Київ: ТОВ «Вид-во «Кліо», 2019. 1120 с., іл.

25. Федоренко М.В. Утвердження шляхти та козацтва, як предтечі державної служби в Україні та Польщі, 3 кін. XV ст. - до Люблінської унії 1569 року. Експерт: парадигми юридичних наук і державного управління. 2021. № 4(16). С. 118-134.

26. Савельев Е.П. Древняя история казачества (Историческое исследование). Часть І-я. Новочеркасск: Тип. «Донской Печатник», 1915. С.11.

27. Історія державної служби в Україні: у 5 т. Від. ред. Т.В. Мотренко, В.А. Смолій; редкол. С.В. Кульчицький та ін. Голов. упр. держ. служби; Ін-т історії НАН України. Т. 3: Документи і матеріали. V ст. до.н.е. - 1774 р. Упорядн.: Г.В. Боряк (кер. кол. упор.), Л.Я. Демченко, Ю.А. Мицик. С. 322-324.

\section{References:}

1. Pol'shha - narisi istoriï. Za red. V. Mendzhec'kogo ta C. Bracisevicha. Per. z pol. I. Svarenka / Institut nacional'noï pam'jati Respubliki Pol'shha. Varshava: Institut nacional'noï pam'jati, 2015. 367 s., il.

2. Jablochkov M. Istorija dvorjanskogo soslovija $v$ Rossii. S.-Peterburg: Tipogr. A.M. Kotomina, 1876. XVI, XL, 679 s.

3. Ustrjalov N.G. Russkaja istorija. Chast' vtoraja (1462-1689). Sanktpeterburg: V Tip. Imperatorskoj Rossijskoj akademii, 1837. [2], 378 s., 1 1. tabl.

4. Kulish P.A. Istorija vossoedenenija Rusi. Tom pervyj. Ot nachala kolonizacii opustoshennoj tatarskim pogromom Kievo-Galickoj Rusi do nachala stoletenej kozacko-shhljahetskoj vojny. S.-Peterburg: Izd-e Tovar-a «Obshhestvennaja pol'za», 1874. IV s., III s., 363 s., prilozh. S. 320-363.

5. Efimenko A.Ja. Istorija ukrainskogo naroda. Vypusk pervyj. Vypusk vtoroj. 9 risunkov v tekste i 12 na otdel'nyh tablicah. S.-Peterburg: Tipogr. Akc. Obshh. Brokgauz-Efron, 1906. 391 s., il.

6. Vasilenko N.P. Ocherki po istorii Zapadnoj Rusi i Ukrainy. Kiev: Izd-e knizhnogo magaz. N.Ja. Ogloblina, 1916. 589 s.

7. Kopistjans'kij A. Istorija Rusi. Chast' druga: Moskovska i Litovsko-Pol'ska doba (Velika i Mala Rus' do chasiv B. Hmel'nic'kogo). L'viv: Izdanie Obshhestva im. M. Kachkovskogo, 1932. 343 s., 3 s., 6 s.

8. Antonovich V.B., Bec V.A. Istoricheskie dejateli Jugo-zapadnoj Rossii v biografijah i portretah po kollekcii Tarnovskogo V.V. Vypusk pervyj. Kiev: Tipograf. Imperatorskogo Un-ta Sv. Vladimira, 1885. VI s., 110 s.; il.

9. Beljaev I. O storozhevoj, stanichnoj i polevoj sluzhbe na Pol'skoj Ukraine Moskovskogo gosudarstva do carja Alekseja Mihajlovicha. Moskva: V Universit. tipograf., 1840. 86 s.; kart.

10. Bantysh-Kamenskij D.N. Istorija Maloj Rossii ot vodvorenija slovjan v sej strane do unichtozhenija get'manstva. Kiïv: Chas, 1993. 656 s., il.

11. Grushevskij M. Ocherki istorii Ukrainskogo naroda. Izd-e tret'e, dopoln. Kiev: Tipograf. 1-oj Kievskoj Arteli Pechati, 1911. 408 s.

13. Konis'kij G. Istorija Rusov ili Maloj Rossii. Redakc. i vstup. stat. O. Ogloblina. N'ju-Jork: Vid-vo «Visnik»- OOChSU, 1956. 346 s.

14. Kulish P.A. Istorija vossoedenenija Rusi. Tom pervyj. Ot nachala kolonizacii opustoshennoj tatarskim pogromom Kievo-Galickoj Rusi do nachala stoletenej kozacko-shhljahetskoj vojny. 
S.-Peterburg: Izd-e Tovar-a «Obshhestvennaja pol'za», 1874. IV s., III s., 363 s., prilozh. S. 320-363.; Kulish P.A. Istorija vossoedenenija Rusi. Tom vtoroj. Ot nachala kozacko-shhljahetskoj vojny do vosstanovlenija V Kieve Pravoslavnoj Cerkvi v 1820 godu. S.-Peterburg: Izd-e Tovar-a «Obshhestvennaja pol'za», 1874. VIII s., III s., 456 s., prilozh. S. 425-456.

15. Markevich N. Istrija Malorossii. Izd-e knigotorg. O.I. Hrustaleva. Tom pervyj. Moskva: V Tipograf. A. Semena pri Imperat. Mediko-Hirurg. Akadem., 1842. 387 s., X.

16. Polons'ka-Vasilenko N. Istorija Ukraïni. V dvoh tomah. I tom (do pol. XVII storichchja). Mjunhen: Ukraïns'ke vid-vo, 1972. 591 s.

17. Javornic'kij D.I. Istorija zaporoz'kih kozakiv. U tr'oh tomah. Redkol.: P.S. Sohan' (vidp. red.) i in. Peredm. V.A. Smolija. Tom 1. Kiïv: Nauk. dumka, 1990. 592 s.; Javornic'kij D.I. Istorija zaporoz'kih kozakiv. U tr'oh tomah. Redkol.: P.S. Sohan' (vidp. red.) i in. Tom 2. Kiïv: Nauk. dumka, 1990. 560 s.; Javornic'kij D.I. Istorija zaporoz'kih kozakiv. U tr'oh tomah. Redkol.: P.S. Sohan' (vidp. red.) i in. Tom 3. Kiïv: Nauk. dumka, 1990. 560 s.

18. Rusina O.V. Ukraïna pid tatarami i Litvoju. Kiïv: Vid. dim «Al'ternativa», 1998. 320 s..

19. Plohij S. Brama Cvropi. Istorija Ukraïni vid skifs'kih vo€n do nezalezhnosti. Harkiv: Klub simejnogo dozvillja, 2016. $495 \mathrm{~s}$.

19. Boplan G. L. de. Opis Ukraïni, kil'koh provincij Korolivstva Pol'skogo, shho tjagnut'sja vid kordoniv Moldoviï do granic' Transil'vaniï, razom z ïnimi zvichajami, sposobom zhittja i vedennja vo€n. Kiïv: Naukova dumka; Kembridzh (Mas.): Ukr. nauk. in-t, 1990. 256 s.: il.

20. Sheval'€ P. Istorija vijni kozakiv proti Pol'shhi, z rozvidkoju pro ïhn€ pohodzhennja, kraïnu, zvichaï, sposib pravlinnja ta religiju i drugoju rozvidkoju pro perekops'kih tatar. Per. z franc. vid. 1663 roku. Kiïv: Vid-vo Akad. nauk URSR, 1960. 199 s.

21. Engel' J.H. Istorija Ukraïni ta ukraïns'kih kozakiv. Zag. red., vstup. stat. V.V. Kravchenka; uporjad. T.O. Chuguja. Harkiv: Fakt, 2014. 640 s.

22. Jakovenko N.M. Ukraïns'ka shljahta z kincja XIV - do seredini XVII stolittja. Volin' i Central'na Ukraïna: monograf. / Ukr. nauk. in-t Garvard. Un-tu, In-t Kritiki. Vid. 2-ge, peregl. i vipr. Kiïv: Kritika, 2008. 469 s.: il.

23. Smolij V., Stepankov V. Ukraïns'ka nacional'na revoljucija XVII st. (1648-1676 rr.). Kiïv: Vid. dim «Kiєvo-Mogil. akad.», 2009. 447 s.

24. Shevchuk V. Kozac'ka derzhava jak ideja v sistemi suspil'no-politichnogo mislennja XVIXVIII stolit' / U dvoh knigah. Kniga 1. Kiïv: TOV «Vid-vo «Klio», 2019. 792 s., il.; Shevchuk V. Kozac'ka derzhava jak ideja v sistemi suspil'no-politichnogo mislennja XVI-XVIII stolit' / U dvoh knigah. Kniga 2. Kiïv: TOV «Vid-vo «Klio», 2019. 1120 s., il.

25. Fedorenko M.V. Utverdzhennja shljahti ta kozactva, jak predtechi derzhavnoï sluzhbi v Ukraïni ta Pol'shhi, z kin. XV st. - do Ljublins'koï uniï 1569 roku. Ekspert: paradigmi juridichnih nauk i derzhavnogo upravlinnja. 2021. № 4(16). S. 118-134.

26. Savel'ev E.P. Drevnjaja istorija kazachestva (Istoricheskoe issledovanie). Chast' I-ja. Novocherkassk: Tip. «Donskoj Pechatnik», 1915. S.11.

27. Istorija derzhavnoï sluzhbi v Ukraïni: u 5 t. Vid. red. T.V. Motrenko, V.A. Smolij; redkol. S.V. Kul'chic'kij ta in. Golov. upr. derzh. sluzhbi; In-t istoriï NAN Ukraïni. T. 3: Dokumenti i materiali. V st. do.n.e. - 1774 r. Uporjadn.: G.V. Borjak (ker. kol. upor.), L.Ja. Demchenko, Ju.A. Micik. S. 322-324. 